\title{
Deutsche Wortforschung
}

Heft 1

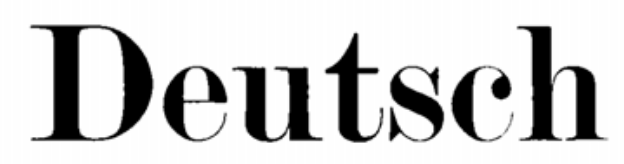

Eine wortgeschichtliche Untersuchung

von

Willy Krogmann

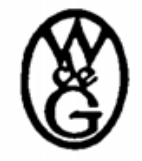

Berlin und Leipzig

Walter de Gruyter \& Co.

vormals G. J. Göschen'sche Verlagshandlung - J. Guttentag. Verlagsbuchhandlung . Georg Reimer . Karl J. Trübner . Veit \& Comp.

$\begin{array}{llll}1 & 9 & 3 & 6\end{array}$ 
Printed in Germany

Archiv-Nr, 452735

Druck von C. G. Rőder A.-G.: Leipzi̊ 